\title{
Comparative Analysis of Circular Economy Implementation in Poland and other European Union Countries
}

\author{
Anetta Zielińska \\ Wroclaw University of Economics and Business \\ Wrockaw, Poland \\ anetta.zielinska@ue.wroc.pl
}

Abstract. Economic development is the factor determining the volumes of generated waste, the intensity of production, the level of individual consumption as well as consumption patterns. It results in environmental threats, which are addressed through practical application of the circular economy concept. The key goal of the latter is to manufacture and use products in the most efficient way and also to manage the resulting waste in an economically and environmentally appropriate manner. In relation to the above, the purpose of the article is to conduct a multivariate comparative analysis covering the European Union countries in terms of their levels of circular economy implementation, with special attention being paid to Poland. The article discusses the concept of circular economy, its principles and major activities. The EU and national-level documents which describe the basics of circular economy are briefly overviewed. The empirical research was carried out using multivariate comparative analysis based on the indicators describing circular economy implementation in all European Union countries. The final part of the article assesses the level of circular economy implementation in Poland specifically.

Keywords: circular economy, waste, depletion of resources, multivariate comparative analysis, Poland, EU.

JEL Classification: Q01, Q53, Q56, Q32, C38

\section{INTRODUCTION}

Natural environment is exposed to numerous threats, including: high greenhouse gas emissions, excessive exploitation of raw materials (both renewable and non-renewable ones), the use of energy from fossil fuels, significant amounts of waste. Attention should be paid to improper waste management, which has negative impacts on the environment quality and eventually also on human health. It is necessary to modify the methods used in exploitation of environmental resources, because already in 2030 the European Union is to obtain, from its own sources, only $12 \%$ of oil, $19 \%$ of gas and $34 \%$ of coal and thus 
will be forced to import the remaining shares of raw materials (Hausner et al., 2015, p. 34; Koziuk et al., 2018; Ślusarczyk and Kot, 2018). The condition ensuring sustainable, low-carbon, resource-efficient, competitive economy is implementation of the circular economy concept in practice (Nitsenko et al., 2018; Rajnoha et al., 2016). Proper development of circular economy depends primarily on achievements of technological revolution and on other significant changes in the processes of production, consumption and waste disposal (Štreimikiené et al., 2016; Simionescu et al., 2017).

Already back in 1976, in a research report for the European Community, W. Stahel and G. Reday presented the vision of circular economy and its impact on: job creation, economic competitiveness, resource saving and waste prevention (Stahel, Reday, 1976 ). In the 1980s, however, W. McDonough and M. Braungart developed the concept of "Cradle to Cradle TM" (www.cradletocradle.com). As a result, in 2014, the concept of circular economy was described in the communication from the European Commission "Towards a circular economy: a zero waste programme for Europe" (European Commission, 2014), and the next communication from the European Commission "Closing the loop - an EU action plan for the Circular Economy" presented a more detailed description of the circular economy concept (European Commission, 2015).

Circular economy is the subject of interest in business, politics and science. A few definitions of circular economy are presented below to clarify the idea of the discussed concept. Circular economy is defined as renewable and reproducible due to designing goods in a way which ensures the highest level of usability and value of products, components and materials throughout their life cycle (Ellen MacArthur Foundation, 2013, p. 22). Another approach addresses circular economy as the restructuring of industrial systems towards supporting natural systems through applying such methods as recycling, which allow higher resource efficiency and ensure minimization of pollution emission and waste generation (Preston, 2012, p. 3). In the context of circular economy, the European Union's aspiration is to create a "recycling society", the goal of which is "to avoid waste generation and to use waste as resources" adopted in the form of the European Community directive in the field of waste management (Directive 2008/98/EC).

The detailed assumptions regarding the functioning of circular economy are presented in the communication from the European Commission (European Commission, 2014):

1) reducing the quantity of materials required to deliver a particular service (lightweighting);

2) product life extension (durability);

3) designing products to reduce the use of energy and materials which are hazardous or difficult to recycle;

4) creating markets for secondary raw materials (recyclates);

5) ecodesign - products easier to maintain, repair, modernize, remanufacture or recycle;

7) developing services for consumers (maintenance/repair);

8) encouraging segregation and using collection systems to minimize recycling and reuse costs;

9) stimulating conditions boosting consumer choices through lease, rental or sharing services.

At this point, three key principles constituting the basis for the circular economy should be presented (Ellen MacArthur Foundation, 2015, pp. 5-8):

1) preserve and enhance natural capital by controlling finite stocks and balancing renewable resource flows (for example, replacing fossil fuels with renewable energy or using the maximum sustainable yield method to protect fish stocks);

2) optimize the yield on resources, using products, components and materials in closed circuits, while maintaining their constant highest usability, both in technical and biological cycles (for example, by sharing products or creating closed loops and extending the life of products); 
3) establish system efficiency - by redesigning the system - through revealing and removing the negative external impacts such as water, air, soil and noise pollution, climate change, toxins, congestion and negative health effects associated with resource use.

Circular economy primarily means ensuring the functioning of materials and resources in the economy for as long as possible. This concept implies cooperation, which means that business models and enterprise functioning frameworks should change, whereas consumers and the legal and institutional environment should be prepared for such changes (Krysovatyy et al., 2018; Razminiene, 2019; JonekKowalska, 2019). The assumption of circular economy is also to implement full waste recovery at the local level (Council of Ministers, 2019, p. 14). The basic goal of circular economy is that the product is manufactured and used as efficiently as possible, and the resulting waste is managed in the most economically and environmentally appropriate manner (European Commission, 2015). Another goal of circular economy is to reduce the extraction of primary natural resources, in particular non-renewable ones, so as to use and process the "circulating" raw materials to the greatest extent, as well as upgrade their properties and value using new technologies, which should translate into minimizing emissions and waste. The circulating resources, once in use, shall reduce the dependence on raw materials (extracted in the country or imported from outside the European Union), increase the competitiveness of countries, minimizing the flow of raw materials to and from the economy and reducing the environmental pressure.

Circular economy will be supported at all stages of the value chain - from its design through production, consumption, repair and regeneration to waste management and obtaining secondary raw materials, which are then recycled in the economy. It is important that the generated waste is approached as the potential secondary raw materials. The European Union is gradually seeking to implement the related best practices and encourage waste management investments. At the same time, sustainable extraction of raw materials on a global scale will be supported too (Council of Ministers, 2019, p. 36).

The EU law has introduced the hierarchy of waste management (Directive 2008/98/EC, Chapter I, Article 4) methods, following which waste generation should be prevented (e.g., through reusing objects and/or materials), and if waste has already been generated, it should be prepared for further reuse and thus it should become subject to recycling or other recovery processes. If the waste cannot be used, it should be disposed of, with landfilling as the least desirable method of waste management. The main factor determining the amount of generated waste is economic development, which affects the intensity of production and the level of individual consumption as well as the patterns of such consumption (Council of Ministers, 2019, Załącznik 1, p. 238; ; Smerichevskyi et al., 2018).

In view of the above, the purpose of the article is to carry out a multivariate comparative analysis based on the Eurostat data, using the indicators describing circular economy within the European Union countries, indicating which countries are at the forefront of its development and which are not handling the level of circular economy implementation effectively, special attention being paid at this to Poland.

\section{LITERATURE REVIEW}

The presented article is based on extensive EU and national literature studies. Two communications from the European Commission played an important role in preparing the article ("Towards a circular economy: a zero waste programme for Europe" and "Closing the loop - an EU action plan for the Circular Economy") as well as the report issued by the Club of Rome (The circular economy and benefits for society: Jobs and climate clear winners in an economy based on renewable energy and resource efficiency. A study pertaining to the Czech Republic and Poland). They were verified by the assessment of ecological policy carried out in Poland, in terms of the circular economy, taking the form of a resolution of the Council of Ministers (dated September 6, 2019 on the adoption of the "2030 ecological policy of the state - the development strategy in the field of environment and water 
management'). The analysis of the level of circular economy implementation was illustrated based on the current Eurostat database and domestic statistical studies developed by the Statistics Poland, which diagnosed the level of the circular economy concept implementation.

\subsection{The European Union guidelines}

The EU policy regarding the level of circular economy implementation places an increasing emphasis on the efficient management of raw materials from the early stage of their extraction, through the design, production, consumption, up to waste collection and management. In this context, it is important to open to other areas of socio-economic life and go beyond the traditionally understood tools of environment management, which should support the development of new business models, development of the service sector, the substitution of currently used raw materials or the production and consumption methods ("Monitor Polski", 2019, p 26).

The European Union set targets regarding waste prepared for reuse and recycling to be met by 2025 and 2030 for the following types of waste (Directive (EU) 2018/850; Directive (EU) 2018/851; Directive (EU) 2018/852):

- municipal waste $(60 \%$ by $2025,65 \%$ by 2030$)$,

- packaging waste $(65 \%$ by $2025,75 \%$ by 2030$)$ and

- up to $10 \%$ reduction of municipal solid waste storage by 2030 .

In 2017, of the total amount of municipal waste generated in the European Union, 30\% was recycled, $29 \%$ was thermally neutralized, $23 \%$ was landfilled, $17 \%$ was composted. The average amount of municipal waste generated per capita in the European Union in 2017 was $486 \mathrm{~kg}$ (Environmental protection 2019, 2019, pp. 154-155).

\subsection{The implementation of the circular economy concept by Poland}

The activities focused on full waste hierarchy implementation in Poland remain a part of the circular economy concept. According to its assumptions, it is of utmost importance to ensure the implementation of activities placed at the top in the hierarchy of waste management methods, and thus prevent their generation as well as create the necessary infrastructure for selective waste collection at source to ensure their preparation for reuse or an effective recycling ("Monitor Polski", 2019, p. 60).

The Polish government's response to the guidelines of the circular economy concept was the resolution adopted by the Council of Ministers on the adoption of the "Roadmap of transformation towards a circular economy", which is one of the strategic projects of the "The responsible development strategy" (Council of Ministers, 2017). The four priority issues which should contribute to the transition into circular economy in Poland (Council of Ministers, 2017, p.6) are listed below:

1) innovation, strengthening cooperation between the industry and the science sector, and as a result implementing innovative solutions in the economy,

2) creating the European market for recyclable materials allowing their enhanced flow,

3) ensuring high quality of secondary raw materials resulting from sustainable production and consumption,

4) development of the service sector as an element necessary to develop the circular economy.

Having analysed the dynamics of changes in the amount of generated waste, the main source of waste in Poland, in 2018, as in the previous years were as follows: mining and quarrying (53.2\%), industrial processing $(22.6 \%)$ and also electricity, gas, steam, hot water (15.9\%) production and supply. 
In 2018, comparing to 2017 , an increase by $1.4 \%$ was recorded in the amount of generated industrial waste. The share of recovered industrial waste was at the level of $50.7 \%$, while $43 \%$ was landfilled and $5 \%$ was disposed of in a different way (Environmental protection 2019, p. 150).

In addition, in 2018 against 2017, an increase by $4.3 \%$ in the amount of generated municipal waste was recorded. It means an increase in the amount of municipal waste generated per capita from $311 \mathrm{~kg}$ in 2017 to $325 \mathrm{~kg}$ in 2018 . Household waste accounted for $83.7 \%$ of all generated municipal waste, whereas the collected municipal waste in 2018 was subjected to the following processes (Environmental protection 2019, 2019, p. 154; Environmental Protection in 2018 ..., 2019, p. 4):

- $56.9 \%$ recovery, including: recycling $(26.2 \%)$, biological processing (composting or fermentation) (8.1\%), thermal energy recovery conversion $(22.6 \%)$,

- disposal $43.1 \%$, including: by thermal conversion with no energy recovery $(1.5 \%)$, by storage $(41.6 \%)$.

The low share of renewable energy raises concerns, although investments in wind energy are increasing and the benefits of solar energy are being explored. They have a good potential for using biomass (e.g., based on residual materials from agriculture and forestry) (Wijkman \& Skånberg, 2016, p.33; Navickas et al., 2017).

\section{METHODOLOGICAL APPROACH}

The research results presented in the article were collected using the multivariate comparative analysis (MCA) method for the European Union countries based on the indicators describing circular economy in the Eurostat database. The obtained results will show which countries are at the forefront and which are not handling the level of circular economy implementation effectively, primarily in relation to Poland

The diversity of data available in comparative analyses, describing the phenomenon of circular economy, implies the need for using multiple measuring units presenting different values, which makes comparing the situation in various areas, or even in the same area, with the changing intensity of particular phenomena types impossible. Therefore, it is founded to search for such methods which allow for the procedure objectification aimed at the general assessment of the circular economy state, therefore the method of multivariate comparative analysis, in the form of linear ordering, can be applied in this case (Zeliaś 1989; Pluta 1986; Pociecha et al. 1988). Linear ordering, using a synthetic development measure (SDM) allowed to rank the objects (countries) "from the best to the worst one" (Walesiak, 2006; Walesiak \& Gatnar, 2009].

The defined research problem, i.e. the level of circular economy implementation in the European Union countries, is a highly complex issue. The classified objects (countries) are described using many indicators, which results in difficulties associated with the assessment of objects' similarity, and thus their classification. The level of objects' similarity regarding one feature may be different than the similarity of the same objects in terms of another feature, therefore the need arises to classify objects using formal procedures, allowing an objective study in the conditions of the complexity characteristic for the circular economy phenomenon.

The first step of a multivariate comparative analysis consists in unifying the nature of variables (indicators describing circular economy). Such unification is not carried out when all variables represent stimulants, i.e. affect positively the analysed collective phenomenon (state of the circular economy). If the 
set of indicators includes destimulants or nominants, it is necessary to convert them into stimulants (Pluta, 1986) ${ }^{1}$.

In the article the conversion of destimulants into stimulants was used by applying a quotient form (Walesiak, 1993, pp.38-40; Piersiala, 2019, p. 171; Tatarczak \& Boichuk, 2018, p. 364; Nowak, 2018, p. 385):

$$
S_{i j}=b\left[D_{i j}\right]^{-1}
$$

where: $\quad \mathrm{D}_{i j}-$ value of $j$-th destimulant observed in $i$-th object (country),

$\mathrm{b}$ - constant adopted arbitrarily, in calculations $\mathrm{b}=\operatorname{minD}_{i j}$,

The next step in the process of multivariate comparative analysis is removing values of the studied variables (circular economy indicators) and unifying orders of magnitude to allow their comparability (socalled normalization) (Walesiak, 1988, pp. 63-71). The following normalization formula was used here (Jajuga, Walesiak, 2000, p.109):

$$
z_{i j}=\frac{x_{i j}-\bar{x}_{j}}{S_{j}}
$$

where: $\quad z_{i j}-$ normalized value of $j$-th of a given circular economy indicator in $i$-th object (country),

$\bar{x}_{j}$ - arithmetic mean of $j$-th of a circular economy indicator,

$\mathrm{S}_{j}-$ standard deviation of $j$-th circular economy indicator,

$\mathrm{x}_{i j}$ - value of $j$-th circular economy indicator observed in $i$-th object (country).

After applying the normalization formula to all indicators of the circular economy, a normalized data matrix (Z) is developed and used for further calculations (see Zielińska \& Sej-Kolasa, 2004).

After determining the normalized data matrix, the hierarchical classification uses the methods of linear ordering for the set of objects. These methods are applied to rank (order) the objects or their sets according to the adopted criterion. These methods can be used only if a certain overriding criterion can be adopted, following which it is possible to rank the objects from the "best" to the "worst". The synthetic development measure (SDM) is the tool in linear ordering methods, which is the function aggregating partial information included in individual indicators and is designated for each object from the sets of objects. The aggregation formulas for indicator values can generally be divided into model and non-model ones (for more see: Gatnar \& Walesiak, 2004, pp. 351-355; Grabiński, 1984, p. 38).

A non-model formula was used in the calculations, where $\mathrm{p}_{i}$ takes the mean normalized value of circular economy indicators for individual countries. The "best" country is the one taking the max $\mathrm{p}_{i}$ value, while the "worst" - min $\mathrm{p}_{i}$ :

$$
p_{i}=\frac{1}{m} \sum_{j=1}^{m} z_{i j}
$$

where: $p_{i}-$ synthetic development measure for $i-$ th object (country),

$m$ - number of data describing the circular economy indicators,

$z_{i j}-$ normalized value of $j$-th of a given circular economy indicator in $i$-th object (country).

\footnotetext{
${ }^{1}$ The set of variables describing circular economy may include: stimulants, destimulants and nominants. Stimulants represent the variables which higher numerical values imply the desired changes of a given phenomenon. Destimulants are the variables which higher values indicate undesirable changes in the studied phenomenon. The nominant features are characterized by a certain level of saturation, any deviations from which imply negative changes in the analyses phenomenon (Pluta, 1986).
} 


\section{CONDUCTING RESEARCH AND RESULTS}

The comparative analysis was carried out using the determinable indicators describing the circular economy for each European Union country. The indicators were obtained from the Eurostat database for 2017. 11 circular economy indicators were selected for the research, which describe the European Union countries in Table 1:

1. Recycling rate of municipal waste (\% percentage).

2. Generation of municipal waste per capita.

3. Recycling rates for packaging waste - glass packaging (\%).

4. Recycling rates for packaging waste - plastic packaging (\%).

5. Recycling rates for packaging waste - paper and cardboard packaging (\%).

6. Recycling rates for packaging waste - wooden packaging $(\%)$.

7. Recycling rate of e-waste (\%).

8. Share of renewable energy in gross final energy consumption (\%).

9. Energy productivity (Euro per kilogram of oil equivalent).

10. Greenhouse gas emissions per capita.

11. Eco-innovation index (Index, $\mathrm{EU}=100$ ).

Table 1

The most important information for the circular economy indicators covering the European Union countries for 2017

\begin{tabular}{|c|c|c|c|c|c|}
\hline Indicators & $\begin{array}{l}\text { Arithmetic } \\
\text { mean }\end{array}$ & $\begin{array}{l}\text { Standard } \\
\text { deviation }\end{array}$ & $\begin{array}{l}\text { Nature of variables: } \\
\text { S-stimulant D- } \\
\text { destimulant }\end{array}$ & $\begin{array}{l}\text { Levels max } \\
\text { for } \mathrm{S} \text { and } \\
\text { min for } \mathrm{D}\end{array}$ & $\begin{array}{c}\text { Country with the the best } \\
\text { level according to } \mathrm{S} \text { or } \mathrm{D} \\
\text { variable }\end{array}$ \\
\hline $\begin{array}{l}\text { Recycling rate of municipal } \\
\text { waste }\end{array}$ & 37,7 & 14,7 & S & 67,6 & Germany \\
\hline $\begin{array}{c}\text { Generation of municipal waste } \\
\text { per capita }\end{array}$ & 482,9 & 109,4 & $\mathrm{D}$ & 272,0 & Romania \\
\hline $\begin{array}{l}\text { Recycling rates for packaging } \\
\text { waste - glass packaging }\end{array}$ & 69,8 & 20,6 & S & 100,0 & Belgium \\
\hline $\begin{array}{l}\text { Recycling rates for packaging } \\
\text { waste - plastic packaging }\end{array}$ & 43,0 & 12,9 & S & 74,2 & Lithuania \\
\hline $\begin{array}{c}\text { Recycling rates for packaging } \\
\text { waste - paper and cardboard } \\
\text { packaging }\end{array}$ & 84,4 & 11,2 & S & 116,1 & Finland \\
\hline $\begin{array}{l}\text { Recycling rates for packaging } \\
\text { waste - wooden packaging }\end{array}$ & 38,9 & 24,8 & S & 89,9 & Portugal \\
\hline Recycling rate of e-waste & 42,0 & 15,1 & $S$ & 81,3 & Croatia \\
\hline $\begin{array}{l}\text { Share of renewable energy in } \\
\text { gross final energy consumption }\end{array}$ & 20,5 & 12,0 & S & 54,5 & Sweden \\
\hline Energy productivity & 7,2 & 3,6 & $\mathrm{~S}$ & 18,3 & Ireland \\
\hline $\begin{array}{c}\text { Greenhouse gas emissions per } \\
\text { capita }\end{array}$ & 9,3 & 3,3 & $\mathrm{D}$ & 5,5 & Sweden, Malta \\
\hline Eco-innovation index & 92,8 & 29,1 & $\mathrm{~S}$ & 144,0 & Sweden \\
\hline
\end{tabular}

Source: own compilation on the basis of www.ec.europa.eu/ eurostat

The above set of indicators for the EU countries does not include much information describing circular economy, as the current data are unavailable (insufficient data for 2018). In the case of 7 indicators (No. 1-7) their levels for several countries were taken from 2016, because in these countries the data are collected in a 2-year cycle and the latest data come from 2016. 
The postulate of uniform preference was carried out for the analysed indicators (formula 1 was used), among which 2 and 10 (indicator numbers) were classified as destimulants, based on a subjective assessment, whereas nominants were not listed among the analysed indicators.

Based on the results presented in Tab. 1 it is noticeable that the best levels of circular economy indicators, according to $\mathrm{S}$ or $\mathrm{D}$ variable, are recorded three times in Sweden.

Next the indicators were normalized (formula 2 was used), i.e. the indicator values were removed and the orders of magnitude were unified to make them comparable.

Finally, a linear ordering was carried out in the form of a synthetic development measure (SDM) (Table 2).

Table 2

Synthetic development measure (SDM) for the level of circular economy by the European Union countries

\begin{tabular}{|c|c|c|c|c|c|}
\hline Country position & Country name & SDM & Country position & Country name & SDM \\
\hline 1 & Sweden & 53,06 & 15 & Lithuania & 39,93 \\
\hline 2 & Denmark & 50,19 & 16 & France & 39,78 \\
\hline 3 & Finland & 47,87 & 17 & United Kingdom & 39,79 \\
\hline 4 & Germany & 46,96 & 18 & Latvia & 37,12 \\
\hline 5 & Slovenia & 45,84 & 19 & Bulgaria & 36,71 \\
\hline 6 & Belgium & 45,76 & 20 & Slovakia & 36,39 \\
\hline 7 & Netherlands & 44,93 & 21 & Croatia & 35,89 \\
\hline 8 & Luxembourg & 44,59 & 22 & Estonia & 34,06 \\
\hline 9 & Ireland & 44,27 & 23 & Romania & 32,75 \\
\hline 10 & Austria & 44,09 & 24 & Poland & 32,50 \\
\hline 11 & Italy & 43,43 & 25 & Greece & 31,96 \\
\hline 12 & Spain & 43,25 & 26 & Hungary & 30,24 \\
\hline 13 & Czech Republic & 41,66 & 27 & Cyprus & 28,54 \\
\hline 14 & Portugal & 41,32 & 28 & Malta & 20,28 \\
\hline
\end{tabular}

Source: author's compilation

Sweden, Denmark and Finland represent the best European Union countries regarding high level of the circular economy concept implementation. Germany was ranked in fourth position only. In turn, Malta, Cyprus and Hungary were the worst in terms of the circular economy practical implementation, whereas Poland was ranked as 25 out of 28 countries.

Such a low position of Poland is, among others, the consequence of the worst results of the three analysed indicators:

1) glass packaging recycling rate;

2) energy productivity and

3) eco-innovation index.

In addition, none of the studied indicators showed the best result for Poland in the group of all countries.

The system of collecting glass packaging in Poland is poorly developed, hence such a low level of glass packaging recycling rate. It is not a municipal waste fraction subject to mandatory segregation for households which filed a waste segregation declaration. In turn, the low level of energy productivity results, among others, from an inefficient integrated energy market and low innovation level (National Energy and Climate Plan for the years 2021-2030). In 2017 Poland was still some distance from its renewable energy target. Although by 2017 Poland had increased its greenhouse gas emissions in the Effort Sharing 
Decision (ESD) sectors by $13.8 \%$ compared with the ESD base year 2005 (Smarter, greener, more inclusive..., 2019, p. 100).

In 2017 Poland underperforms in four out of five scoreboard components, being particularly weak in $\mathrm{R} \& \mathrm{D}$ and innovation investments and early stage investments in green technologies as well as in economic activities related to eco-innovation. Development of eco-innovation in Poland has been slow as the businesses have not yet been fully able yet to use the potential of the public funding (mostly from EU structural funds) to develop environmental technologies (https://ec.europa.eu/environment/ecoap/poland_en). Gross domestic expenditure on R\&D Poland 2017 (\% of GDP) presents the level of $1 \%$. Public and private gross domestic expenditure on R\&D Poland in 2017 (\% of GDP), i.e. Public R\&D intensity at the level of $0,38 \%$, whereas Private R\&D intensity - 0,7\% (Smarter, greener, more inclusive..., 2019, pp.36-38).

\section{CONCLUSION}

The research findings allow formulating the following conclusions for Poland:

- the priority of the circular economy is to change the approach towards waste policy, primarily including the situation in which waste is converted into resources;

- the identified transition barriers to the circular economy cover funding (large investment outlays), social barriers (low public awareness, e.g., in relation to proper segregation) and technological barriers (low level of eco-innovation);

- four times higher fees will be charged to those who do not segregate waste in accordance with the Act on maintaining the cleanliness and order in communes. It will contribute to proper segregation at source (households producing municipal waste);

- lower fees for residents with household composters, as in 2023 the segregation of bio-waste will be obligatory in the European Union;

- the increase in fees for municipal waste collection also results from higher waste management costs in regional municipal waste treatment installations;

- in the future residents should pay for the amount of generated residual waste which is unsuitable for recycling, recovery and thermal treatment, it will be an incentive for a radical increase in recycling levels;

- support for innovation in exploitation, processing and using raw materials from the secondary circulation, from the resource created by post-use and production waste and the anthropogenic secondary deposits;

- in Poland an increase in primary energy consumption in 2017 left a gap of 2.7 Mtoe that will need to be closed for Poland to meet its 2020 target.

\section{REFERENCES}

Directive (EU) 2018/850 of the European Parliament and of the Council of 30 May 2018 amending Directive 1999/31/EC on the landfill of waste (Text with EEA relevance). (Official Journal of the European Union, L 150, 14 June 2018).

Directive (EU) 2018/851 of the European Parliament and of the Council of 30 May 2018 amending Directive 2008/98/EC on waste (Text with EEA relevance). (Official Journal of the European Union, L 150, 14 June 2018). 
Directive (EU) 2018/852 of the European Parliament and of the Council of 30 May 2018 amending Directive 94/62/EC on packaging and packaging waste (Text with EEA relevance). (Official Journal of the European Union, L 150, 14 June 2018).

Directive 2008/98/EC of the European parliament and of the council of 19 November 2008 on waste and repealing certain Directives (Text with EEA relevance). (Official Journal of the European Union, L 312, 22 November 2008).

Ellen MacArthur Foundation (2015). Towards a Circular Economy: Business Rationale for an Accelerated Transition, $\quad$ Retrieved December $\quad 15, \quad$ from https://www.ellenmacarthurfoundation.org/publications/towards-a-circular-economy-business-rationale-foran-accelerated-transition

European Parliament (2008). Directive 2008/98/EC of the European parliament and of the council of 19 November 2008 on waste and repealing certain Directives (Text with EEA relevance). (Official Journal of the European Union 22 November 2008,L 312, Volume 51).Gatnar, E., \& Walesiak, M. (2004). Metody statystycznej analizy wielowymiarowej w badaniach marketingowych. Wrocław: Wydawnictwo.

Grabiński, T. (1984). Wielowymiarowa analiza porównawcza w badaniach dynamiki zjawisk ekonomicznych. Kraków: Zeszyty Naukowe AE w Krakowie, Seria specjalna monografie nr 61.

Hausner, J., Bromowicz, J., Bukowski, M., Kasztelewicz, Z., Kudłacz, M., Kulczycka, J., Piestrzyński, A., Steinhof, F., \& Wilczyński, M. (2015). Polityka surowcowa Polski - rzecz o tym czego nie ma a jest bardzo potrzebne. Kraków: Fundacja GAP.

https://www.cradletocradle.com

Jajuga K., Walesiak M. (2000). Standardisation of data set under different measurement scales, W: R. Decker, W. Gaul (Eds.), Classification and information processing AT the turn of the millennium, Springer-Verlag, Berlin, Heidelberg, s.109

Jonek-Kowalska, J. (2019). Transformation of energy balances with dominant coal consumption in European economies and Turkey in the years 1990-2017. Oeconomia Copernicana, 10(4). https://doi.org/10.24136/oc.2019.030.

Komisja Europejska (2014). Ku gospodarce o obiegu zamknietym: program „zero odpadón” dla Europy. Komunikat Komisji do Parlamentu Europejskiego, Rady, Europejskiego Komitetu Ekonomiczno-Społecznego i Komitetu Regionów, Bruksela. COM/2014/0398 final.

Komisja Europejska (2015). Zamknięcie obiegu - plan driatania UE dotyczqcy gospodarki o obiegu zamknietym. Komunikat Komisji do Parlamentu Europejskiego, Rady, Europejskiego Komitetu Ekonomiczno-Społecznego i Komitetu Regionów. Bruksela. COM/2015/614 final.

Koziuk, V., Dluhopolskyi, O., Hayda, Y., Shymanska, O. (2018). Typology of welfare states: quality criteria for governance and ecology. Problems and Perspectives in Management, 16(4), 235-245. doi:10.21511/ppm.16(4).2018.20

Krysovatyy, A., Zvarych, I., \& Zvarych, R. (2018). Circular economy in the context of alterglobalization. Journal of International Studies, 11(4), 185-200. doi:10.14254/2071-8330.2018/11-4/13

Nitsenko, V., Mardani, A., Streimikis, J., Shkrabak, I., Klopov, I., Novomlynets, O., \& Podolska, O. (2018). Criteria for Evaluation of Efficiency of Energy Transformation Based on Renewable Energy Sources. Montenegrin Journal of Economics, 14(4), 237-247.

Ochrona środowiska 2019 (2019). Warszawa: Główny Urząd Statystyczny.

Ochrona Środowiska w 2018 r. Informacje sygnalne (2019, czerwiec). Warszawa: Główny Urząd Statystyczny.

Navickas, V., Vojtovic, S., Svazas, M. (2017). Biomass clusters influence on business competitiveness. Polish Journal of Management Studies, 16 (2), 188-197. doi:10.17512/pjms.2017.16.2.16

Nowak, P. (2018). Regional variety in quality of life in Poland. Oeconomia Copernicana, 9(3), 381-401. https://doi.org/10.24136/oc.2018.019.

Piersiala, L. (2019). The usage pattern of development method to assess the functioning of special economic zones: the case of Poland. Equilibrium. Quarterly Journal of Economics and Economic Policy, 14(1), 167-181. https://doi.org/10.24136/eq.2019.008.

Pluta, W. (1986). Wielonymiarowa analiza porównawcza w modelowaniu ekonometrycznym. Warszawa: PWN. 
Pluta, W. (1986). Wielonymiarowa analiza porównawcza w modelowaniu ekonometrycznym. Warszawa: PWN.

Pociecha, J., Podolec, B., Sokołowski, A., Zając, K. (1988). Metody taksonomiczne w badaniach społeczno-ekonomicznych. Warszawa: PWN.

Rada Ministrów (2017, luty) Strategie na rzecz Odpowiedzialnego Rozwoju do roku 2020 (zperspektywa do 2030 r.). Warszawa. Rada Ministrów (2019, październik). Mapy drogowej transformacji w kierunku gospodarki o obiegu zamkniętym. Warszawa

Rady Ministrów (2019). Polityki ekologicznej państwa 2030 - strategii roz̧woju w obszarže środowiska i gospodarki wodnej. Warszawa: Monitor Polski poz. 794, uchwała nr 67.

Rajnoha, R., Lesníková, P., Korauš, A. (2016), From Financial Measures to Strategic Performance Measurement System and Corporate Sustainability: Empirical Evidence from Slovakia, Economics and Sociology, Vol. 9, No 4, pp. 134-152. DOI: 10.14254/2071-789X.2016/9-4/8

Razminiene, K. (2019). Circular economy in clusters' performance evaluation. Equilibrium. Quarterly Journal of Economics and Economic Policy, 14(3), 537-559. https://doi.org/10.24136/eq.2019.026.

Simionescu, M., Albu, L. L., Raileanu Szeles, M., \& Bilan, Y. (2017). The impact of biofuels utilisation in transport on the sustainable development in the European Union. Technological and Economic Development of Economy, 23(4), 667-686.

Ślusarczyk, B., Kot, S. (2018). Solution for sustainable development: Provisions limiting the consumption of disposable plastic carrier bags in Poland. Journal of Security and Sustainability Issues, 7 (3), 449-458. doi:10.9770/jssi.2018.7.3(7)

Smarter, greener, more inclusive? Indicators to support the europe 2020 strategy (2019). Luxembourg: Publications Office of the European Union, 36-38.

Smerichevskyi, S., Kniazieva, T., Kolbushkin, Y., Reshetnikova, I., Olejniczuk-Merta A. (2018). Environmental orientation of consumer behavior: motivational component. Problems and Perspectives in Management, 16(2), 424437. doi:10.21511/ppm.16(2).2018.38

Stahel. W. i Reday. G. (1976). Report The Potential for Substituting Manpower for Energy 1976. New York: Vantage Press.

Štreimikiene, D., Strielkowski, W., Bilan, Y., \& Mikalauskas, I. (2016). Energy dependency and sustainable regional development in the Baltic states: A review. Geographica Pannonica, 20(2), 79-87.

Tatarczak, A., \& Boichuk, O. (2018). The multivariate techniques in evaluation of unemployment analysis of Polish regions. Oeconomia Copernicana, 9(3), 361-380. https://doi.org/10.24136/oc.2018.018.

Walesiak M. (1988). Skale pomiaru cech (w ujeciu zweżonym) a zganienie uyboru postaci analitycznej syntetycznych miernikón rozwoju. Wrocław: Prace Naukowe AE we Wrocławiu nr 447.

Walesiak, M. (1993). Statystyczna analiza wielowymiarowa w badaniach marketingowych. Wrocław: Prace Naukowe AE we Wrocławiu nr 654, Seria Monografie i Opracowania nr 101.

Walesiak, M. (2006). Uogólniona miara odległości w statystycz̨nej analiz̨ie wielowymiarowej, Wrocław: Wydawnictwo Akademii Ekonomicznej we Wrocławiu.

Walesiak, M. \& Gatnar, E. (2009). Statystyczna analiza danych z wykorzystaniem programu R, Warszawa: PWN.

Wijkman, A., Skånberg, K. (2016, June). The Circular Economy and Benefits for Society. Jobs and Climate Clear Winners in an Economy Based on Renewable Energy and Resource Efficiency. A study pertaining to Czech Republic and Poland. Raport The Club od Rome.

Zeliaś, A. (1989). Metody taksonomii numerycznej w modelowaniu zjawisk spoteczno-gospodarczych. Warszawa: PWN.

Zielińska, A., \& Sej-Kolasa M. (2004). Excel w statystyce, materialy do ćmiczeń. Wrocław: Wydawnictwo Akademii Ekonomicznej im. Oskara Langego we Wrocławiu. 